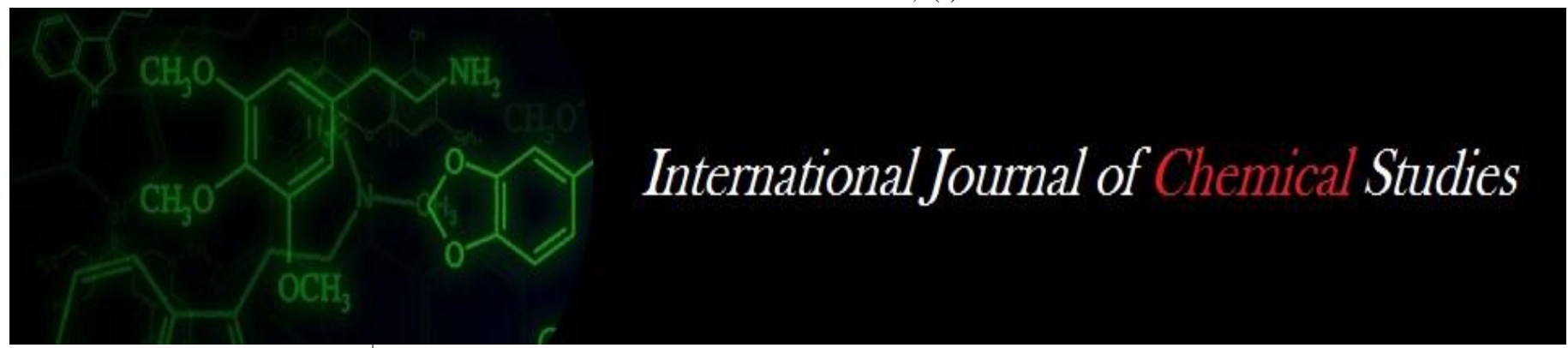

P-ISSN: 2349-8528

E-ISSN: 2321-4902

www.chemijournal.com

IJCS 2021; 9(1): 1382-1385

(C) 2021 IJCS

Received: 04-11-2020

Accepted: 12-12-2020

\section{AJ Patel}

Ph.D., Scholar, Department of Horticulture, B. A. College of Agriculture, Anand Agricultural University, Anand, Gujarat, India

\section{KD Rathod}

Ph.D., Scholar, Department of Horticulture, B. A. College of Agriculture, Anand Agricultural University, Anand, Gujarat, India

\section{BN Satodiya}

Associate Professor, College of Horticulture, Anand Agricultural University, Anand, Gujarat, India
Corresponding Author:

\section{AJ Patel}

Ph.D., Scholar, Department of

Horticulture, B. A. College of Agriculture, Anand Agricultural

University, Anand, Gujarat,

India

\section{Effect of water stress and its management in vegetable crops: A review article}

\section{AJ Patel, KD Rathod and BN Satodiya}

DOI: https://doi.org/10.22271/chemi.2021.v9.i1t.11415

\begin{abstract}
Climate change is the one of the major problem for low production of most of the vegetable crops worldwide that reducing average yield for most of the vegetable crops. Hostile environmental conditions such as drought, water logging, high saline levels, extreme temperatures, nutrients and other factors pose serious problems in production of vegetables. Among this water stress adversely affect on functioning of stomata, germination, growth reduction, premature senescence and reduce productivity. Water stress may be of two types i.e. drought and water logging. Mitigation of water stress is very important to reduce the yield loss. The water stress can be mitigating by mulching, use of Plant Growth Regulators, antitranspirants, hydrogel, grafting techniques and use of resistant varieties.
\end{abstract}

Keywords: Water stress, vegetable production, mitigation

\section{Introduction}

Vegetables are the important source of nutrition in Indian Agriculture after cereals and pulses. India secured second rank in vegetable production, next to China by covering an area of 10.1 million ha with the production of 185 million tonnes and productivity of 18.31 tonnes per ha (Anonymous, 2018) ${ }^{[1]}$. Vegetable plays an important role in human nutrition, called as protective food and this is particularly because of their consumption can defend against several diseases and considered as rich source of minerals, vitamins and fiber with high calorific values.

Abiotic stress constitutes one of the most significant limitations to vegetable production in the world today. Environmental conditions such as drought, high saline levels, extreme temperatures, poor soils and others pose serious problems.

Water stress is considered to be a moderate loss of water, which leads to stomatal closure and limitation of gas exchange. Water stress is characterized by reduction of water content, turgor, total water potential, wilting and decrease in cell growth \& enlargement. In addition, abscisic acid (ABA), a plant stress hormone, induces the closure of leaf stomata (microscopic pores involved in gas exchange), thereby reducing water loss through transpiration. In vegetable crops, management of water stress can bring the production and productivity up to the mark. Management of water stress can be done by application of mulching, use of Plant Growth Regulators, antitranspirants, hydrogel and grafting techniques.

\section{What is water stress?}

Water stress can be defined as the absence of adequate soil moisture necessary for a plant to grow normally and complete its life cycle.

\section{Type of water stress}

Drought stress

It is the situation when there is not enough water to meet all demands, such as those required by an ecosystem to function

\section{Flooding stress}

Plant can't absorb the water due to the salinity, osmotic stress, water logging condition. 


\section{Factors responsible for water stress}

Water stress is one of the most adverse factors of plant growth and productivity and considered a severe threat for sustainable crop production in the conditions on changing climate.

1. Erratic Rainfall

2. Poor Soil Water Storage

3. Less Capillary water in soil

4. Soil type

5. Irrigation channel

6. Saline water irrigation

7. Poor draining system

8. Water- logging

9. Plant architecture (Transpiration \& Water uptake rate)

10. Global warming

11. Deforestation

\section{Effect of Water Stress in Plant \\ Functioning of stomata}

Stomata lose their function and may die, because wilting after certain limit denature the starch in the guard cell and also in the mesophyll cells.

\section{Growth}

Affect Germination, Growth reduction, premature senescence and Reduction productivity.

Carbohydrate metabolism in green leaves: The very first effect of drought on carbohydrate metabolism is that starch disappears from wilted leaves following decrease in soil moisture and sugar accumulates, simultaneously. A low degree of drying stimulates activities of amylase and phosphorylase. The decomposition of carbohydrate beings in leaves where major influence of drought can be observed.

\section{Biochemical effect}

Water shortage in cell profoundly alters the chemical composition of plant, Starch converted into sugar, i.e. an increase in hexose sugar content.

\section{Physiological adaptation to moisture stress \\ Water uptake is improved}

- Extensive root system with large active surface area

- Root/Shoot ratio shifted in favour of the roots

\section{Water loss is reduced \\ - Transpiration reduced \\ - Thick cuticle \\ - Epicuticular waxes \\ - White hairs on leaves \\ - Leaf senescence \\ - Leaf shedding}

\section{Biochemical responses \\ Proline}

Proline can act as a signaling molecule to modulate mitochondrial functions and trigger specific gene expression, which can be essential for plant recovery from stress and Stabilizing sub-cellular structures, scavenging free radicals, maintain membrane integrity and reduces oxidation of lipid membranes under stress conditions

\section{Antioxidant}

Scavenging free radicals regulate number of metabolic process in plants exposed to drought stress and improve drought tolerance by enhancing the antioxidant mechanism

\section{Polyamines}

Polyamines are involved in flower induction, pollination, seed set and stress tolerance mechanism

\section{Late Embryogenesis Abundant Protein}

LEA proteins were initially discovered accumulating late in embryogenesis of cotton seeds and protect the plant against water stress; cold stress and high salinity also prevent protein aggregation due to water stress. They are highly hydrophilic and unstructured Associated with drought tolerance. LEA proteins are protective of mitochondrial membranes against dehydration damage.

Table 1: Effect of drought on growth and development on different vegetables

\begin{tabular}{|c|c|c|}
\hline Vegetable & Critical Stage & Impact of water deficit \\
\hline Tomato & Flowering and fruit enlargement & Flower shedding, BER, reduced fruit size \\
\hline Eggplant & Flowering and fruit development & Less yield, poor color development \\
\hline Chilli and capsicum & Flowering and fruit set & Shedding of flower and fruits \\
\hline Cabbage and cauliflower & Head/curd formation, enlargement & Tip burning, splitting of head and riceyness in cauliflower \\
\hline Root crops & Root enlargement & Distorted, rough and poor roots, splitting, Forking \\
\hline Cucumber & Flowering and fruit development & Bitterness and deformity in fruits \\
\hline Okra & Flowering and pod development & Loss of yield, fiber development \\
\hline Melons & Flowering and fruit development & Poor fruit quality due to less TSS \\
\hline Lettuce & Throughout development & Toughness in leaves, tip burning \\
\hline Pea & Flowering and pod filling & Less root nodulation, poor grain filling \\
\hline Potato & Tuberization and enlargement & Poor tuber growth and yield, splitting \\
\hline Leafy vegetables & Throughout development & Toughness in leaves, poor foliage \\
\hline
\end{tabular}

\section{Management of drought stress}

\section{Mulching}

The technique of covering the soil with natural crop residues or plastic films for soil and water conservation is called mulching. Mulching can be practiced in vegetable crops using crop residues and other organic material available in the farm.

\section{Use of Plant Growth Regulators}

Enhancing plant tolerant through foliar application of EPGR both natural and synthetic, has verified for enhancement growth against a variety of abiotic stresses include drought, under drought stress, EPGR treatments increase water potential inside cell and improved chlorophyll content. Salicylic acid, gibberellin, Brassinosteroid, jasmonic acid, ethylene, auxins and cytokinins are responsible for drought tolerance in plants. $\mathrm{CCC} / \mathrm{CC} / \mathrm{MC}$ and Paclobutrazol Tolerance to water stress in many plant species. Abscisic acid (ABA) responsible for stomata regulation, root development, and initiation of ABA-dependent pathway. 


\section{Antitranspirants}

Antitranspirants generally reduce photosynthesis. Therefore, their use is limited to save the crop from death under severe moisture stress.

Stomata closing: Most of the transpiration occur through the stomata on the leaf surface. Phenyl Mercuric Acetate (PMA) and Atrazine inducing stomatal closing. i.e. 2, $4-\mathrm{D}$, Phosphon-D.

\section{Film forming type}

Plastic and waxy material which form a thin film on the leaf surface and result into physical barrier. Example: Mobileaf, Folicot, Waxol

\section{Reflectance type}

They are white materials which form a coating on the leaves and increase the leaf reflectance. Example: Kaoline, China Clay, Calcium bicarbonate, Lime water.

\section{Growth retardant}

These chemicals reduce shoot growth and increase root growth and thus enable the plants to resist drought. They may also induce stomatal closure. Cycocel is useful for improving water status of the plant.

\section{Hydrogel}

Hydrogel is prepared by grafting and cross-linking of waterabsorbent polymers (polyacrylamide) onto a cellulose derivative backbone polymer chain (carboxymethyl cellulose). Hydrogel can be used effectively as it provides water to the growing plants on needed.

\section{Application of hydrogel}

\section{Field condition}

Prepare an admixture of hydrogel and fine dry soil in 1: 10 ratio and apply along with the seeds/fertilizers or in the opened furrows before sowing.

\section{Nursery bed for transplant}

Apply $2 \mathrm{~g} / \mathrm{m}^{2}$ of hydrogel uniformly in the top 2 inches of the nursery bed. In pot culture, mix $3-5 \mathrm{~g} / \mathrm{kg}$ of hydrogel in soil before planting.

\section{While transplanting}

Thoroughly mix $2 \mathrm{~g}$ of hydrogel per litre of water to prepare a free-flowing solution; allow it to settle for half an hour. Dip the roots of the plant in the solution and then transplant in the field.

Pusa Hydrogel has been licensed to six companies for commercialization. It has become one of the key technlogies of IARI having potentiality to become a leading component in second green revolution.

\section{Grafting technique}

In plant, water deficient condition is first recognized by roots.
But in grafted plant due to higher activity of H+-ATPase enzyme, it promotes large and deep root system to acquire water from the soil. (Sze et al., 1999) ${ }^{[9]}$.

\section{Different methods of grafting}

Tongue approach grafting (Melon and Cucumber), Hole insertion, Splice, Side and Cut grafting (Water melon), Cleft and tube grafting (Tomato, Brinjal and Capsicum), Apical wedge grafting (Capsicum) and Micro Grafting (Tomato)

Table 2: Potential rootstocks with special features of resistance against drought

\begin{tabular}{|c|c|c|}
\hline Crop & Species & References \\
\hline Tomato & Solanum pennelli & Bolger et al. $(2014)^{[4]}$ \\
\hline & S. chilense & Zamir et al. $(1994)^{[10]}$ \\
\hline Brinjal & $\begin{array}{c}\text { Solanum elaeagnifolium } \\
\text { Solanum macrocarpum }\end{array}$ & Christodoulakis et al. $(2009)^{[5]}$ \\
\hline
\end{tabular}

\section{Use of resistant varieties}

Table 3: Varieties developed through breeding method for drought resistance

\begin{tabular}{|c|c|}
\hline Crop & Drought tolerant varieties \\
\hline Tomato & Arka Vikas, Arka Meghali, Kashi Aman \\
\hline Chilli & Arka Lohit \\
\hline Onion & Arka Kalyan \\
\hline Cluster bean & Karan Guar-1 \\
\hline
\end{tabular}

\section{Basic methods of drought management \\ Drip irrigation}

It minimizes water losses due to run-off and deep percolation and water savings of $50-80 \%$ are achieved when compared to most traditional surface irrigation methods.

\section{Water harvesting}

Water harvesting for dry land is a traditional water management technology to ease future water scarcity in many arid and semi arid regions of the world. Rainwater and flood water harvesting have the potential to increase the productivity of arable land.

\section{Protected cultivation}

Protected structures can play important role to minimize the impact of temperature fluctuation, over/under precipitation and fluctuating sun shine hour and its role to minimize the impact of climatic change effect. Seedling rising in pro-trays and crop production inside agro-shade net also gaining popularity among the farmers.

\section{Effect of water logging stress}

1. Gas diffusion limitation (Metabolic toxins (soil or roots), reduced respiration (Energy deficiency), Reduced root Conductivity to water

2. Mineral nutrient deficiency

Table 4: Water stress management

\begin{tabular}{|c|c|c|}
\hline \multicolumn{3}{|c|}{ Drought stress management } \\
\hline Treatment & Result & References \\
\hline Black plastic mulch & Increases yield parameters in chilli cv. Local & Ashrafuzzaman et al. (2011) ${ }^{[2]}$ \\
\hline Foliar spray of NAA $40 \mathrm{ppm}$ at flower bud initiation & Maximize yield in chilli cv. Kashi Anmol & Patel et al. (2016) ${ }^{[7]}$ \\
\hline Foliar application of $0.5 \mathrm{mM} \mathrm{SA}$ at $30 \mathrm{DAP}$ & $\begin{array}{l}\text { Increases yield and quality of } \\
\text { garlic cv. Pinkish Local }\end{array}$ & Bideshki and Arvin (2010) ${ }^{[3]}$ \\
\hline Foliar spraying of cycocel $(5 \mathrm{mM})$ & $\mathrm{C}(\%)$ in growth stage in brinja & $001)$ \\
\hline
\end{tabular}




\begin{tabular}{|c|c|c|}
\hline \multicolumn{3}{|c|}{ Water logging stress management } \\
\hline Treatment & \multicolumn{2}{|c|}{ Result } \\
\hline Grafting-SR pink \& purple on solanum torvum & Higher fruit set and yield \\
\hline
\end{tabular}

\section{Conclusion}

From the above discussion it can be concluded that water stress condition can be manage by use of mulching, PGRs, antitranspirants, hydrogel, proper irrigation method, use of protected structure, grafting on resistant rootstock and cultivation of resistant varieties for water stress condition to maximize vegetable production.

\section{References}

1. Anonymous. Indian Horticulture Data base. National Horticulture Board, Ministry Agriculture, Government of India, New Delhi 2018.

2. Ashrafuzzaman M, Abdul HM, Mohd RI, Shahidullah SM, Alamgir HM. Effect of plastic mulch on growth and yield of chilli. Brazilian Archives of Biology and Technology 2011;54(2):321-330.

3. Bideshki A, Arvin MJ. Effect of salicylic acid (SA) and drought stress on growth, bulb yield and allicin content of garlic (Allium sativum) in field. Plant Ecophysiology 2010;2:73-79.

4. Bolger A, Scossa F, Bolger ME, Lanz C, Maumus F, Tohge QH et al. The genome of the stress-tolerant wild tomato species Solanum pennellii. Nature Genetics 2014;46(9):1034-1039.

5. Christodoulakis NS, Lampri PN, Fasseas C. Structural and cytochemical investigaction of the silverleaf nightshade (Solanum elaeagnifolium), a drought-resistant alien weed of the Greek flora. Australian Journal of Botany 2009;57:432-438.

6. Kumar Sanjeev, Patel NB, Saravaiya SN, Vashi JM. Performance of grafted brinjal cv. Surati Ravaiya onto Solanum torvum Swartz rootstock under excess moisture conditions of South Gujarat, India, International Journal of Tropical Agriculture 2016;34(3):753-760.

7. Patel VP, Lal EP, John SA. Comparative study of the effect of plant growth regulators on growth, yield and physiological attributes of chilli, capsicum annum L. cv Kashi Anmol. International Journal of Farm Sciences 2016;6(1):199-204.

8. Prakash M, Ramachandran K. Effect of moisture stress and anti-transirants on leaf chlorophyll. Journal of Agronomy and Crop Science 2001;184(3):153-156.

9. Sze H, Li X, Palmgren MG. Energization of plant cell membranes by $\mathrm{H}^{+}$-pumping ATPase: regulation and biosynthesis. Plant cell 1999;11:677-689.

10. Zamir D, Ekstein MI, Zakay Y, Navot N, Zeidan M, Sarfatti $\mathrm{M}$ et al. Mapping and introgression of a tomato yellow leaf curl virus tolerance gene, Ty-1. Theoretical and Applied Genetics 1994;88:141-146. 